\title{
The Importance of Self-Motivation Elements in Preparing Fresh Technical Graduates to Face Project-Based Employment
}

\author{
Siti Nur Maizura Binti Sharberi , Yee Mei Heong and Raudhah Adibah Binti Ahmad Zubir
}

\begin{abstract}
Getting a job after graduation is like a dream comes true for every student after graduated. However, issues related to unemployment problems among graduates keeps increasing in the country. One of the main causes of unemployment that occurs among graduates is the rising project-based employment in the industry. Project-based employment is a system of employment in which the workers only work throughout the duration of the project or within a short-term period only. Project-based employment systems are widely implemented in industrial companies to save costs. To face this project-based employment system, students need to have strong skills and self-motivation. If they lack self-motivation, it will be difficult for them to tackle project-based employment. Therefore, the elements of self-motivation are the important fundamentals for students especially in the vocational institutions. Therefore, the elements of self-motivation need to be constantly refined and improved by the institutions to ensure that the graduates are equipped with strong self-motivation elements to work in the project-based employment in future.
\end{abstract}

Keywords: Self-motivation elements, project-based employment.

\section{INTRODUCTION}

Education is an important component in meeting the country's needs and promote the cultural, social, political and economic development of the nation. Excellent education system is not only for the benefit of teaching, but they are capable of producing high quality and semi-skilled workforce [1]. In order to ensure the country can produce high-quality workforce, the institutions need to equip students and graduates with essential workforce attributes.

In addition, institutions need to be more aware of project-based employment systems that are increasingly implemented in our country [2]. Employers in industrial sectors often use project-based employment system to save costs of the companies. Moreover, employers would earn duration of the project that they work only [3].

Revised Manuscript Received on 14 September, 2019.

Siti Nur Maizura Binti Sharberi. Technical and Vocational Education at

Dr Yee Mei Heong senior lecturer. Faculty of Technical and Vocational Education. Universiti Tun Husseion Onn of Malaysia (UTHM).

Raudhah Adibah Binti Ahmad Zubir Technical and Vocational Education, Universiti Tun Hussein Onn Malaysia (UTHM). more profit because they just need to pay the workers for the Universiti Tun Hussein Onn Malaysia (UTHM).

The fresh graduates who are involved in project-based employment environment later will use their existing skills while working. They will also be able to hone and improve their skills [4]. This can also help them to place themselves in various fields of work. Although this project-based employment provide temporary jobs to fresh graduates, it also helps graduates to strengthen their self-motivation, so that they are better prepared to face the challenges in the industry [5].

In Malaysia, the elements of self-motivation embedded in the education system also play an important role in producing skilled and semi-skilled workforce in the world of temporary employment [6]. Graduates with good technical skills, without the elements of self-motivation are still considered not good enough. One study found that there are elements that must be present among technical and vocational graduates to ensure their capabilities of communicating, innovating and being confident in facing challenges at the workplace. The combination of these elements of self-motivation will enhance the graduates' productivity as well as the production of the industrial companies [7].

Therefore, a graduate should view employment as a factor in improving themselves to be a contributor to the company. By improving the quality of work and learning new things at the workplace, graduates are not just getting better along with their employers, but they are also elevating their potential to get better jobs in the future. As such, the vocational institutions need to incorporate self-motivation elements for technical students into project-based employment and help generate new ideas while they are in the industry.

\section{A. Unemployment among Fresh Technical Graduates}

One of the keys to career development for graduates is having a higher education. However, a study conducted by the Malaysia Department of Statistics in 2017 shows that 51,247 undergraduate students were found to be unemployed. The results of the study illustrate that among the factors contributing to the issue of unemployment among fresh graduates is due to the increasing contract job or project-based employment.

\section{Published By:}


This is evidenced by a statement from the President of the Congress of the Unions in the Public Service (CUEPACS) (2017), which estimates that there are 60,500 workers in the public sector who are contracted or hold part-time positions. In addition, the results of the study show that many employers in industrial companies prefer to provide project-based jobs to fresh graduates to minimize business costs.

This is particularly frustrating to the fresh graduates because most of them prefer to work permanently and refuse temporary job [8]. They are now facing tough competition in getting permanent job. In the face of competition for employment, graduates have no choice but need to accept project-based employment while waiting for permanent job offer [9].

On the other hand, the vocational institutions are also used to focusing more on the students' academic regardless of the importance of soft skills in employment such as self-motivation. Institutions pay less attention to the effort of cultivating self-motivation among their students, making them less able to market themselves in the future work environment. Students who possess low self-motivation have a lower chance of getting job and they hardly adapt well to the work environment [10].

The findings of the Ministry of Higher Education (2012) in The National Graduate Employability Blueprint 2012-2017 present some problems that were most frequently identified by employers among graduates. They were lack of confidence in English (55.8\%), lack of knowledge in self-awareness $(37.4 \%)$, asking for unrealistic salaries or benefits $(33 \%)$, skills mismatch $(30.2 \%)$, inability to accept change $(27.7 \%)$, job choice $(25.9 \%)$, as well as poor attitude and personality $(23.8 \%)$. This is a major demand of the industry and it clearly indicates that these are the elements that fresh graduates are lacking.

\section{PROJECT-BASED EMPLOYMENT}

Project-based employment means contract work or temporary employment that causes the workforce to have a limited time frame for working with a company. They work on projects that require only their manpower and skills. The employment-based contract workers are usually not called as employees because they have a period of work in keeping with the project they are working on [11].

Companies or industries that use project-based employment systems will have service contract agreements in the form of legal documents detailing the terms agreed to in the professional contract. The purpose of the contract agreement document is to legally protect the workforce and the company [12]. The contract agreement document requires the workforce and company to sign it as an evidence for future reference.

Project-based employment systems are increasingly being adopted by employers, especially in industrial sector companies such as the construction, mechanical and electrical equipment [13]. They are best suited to use project-based employment systems as the industrial sector requires workers only as the project progresses. In addition, employers will also be able to limit the number of project running simultaneously.

Nowadays, more and more companies, especially in the industry use project-based employment system for labour. This is to reduce cost. The industry will be able to reduce the cost of payroll as the workforce is only working during the project. Besides, the employers can manage the workforce more systematically throughout the project.

The duration of the contract workers have been determined and their level of progress will be assessed based on their performance throughout their contract. The employment period of a contract labourer in the company may be extended annually or monthly. The workforce is also likely to depend entirely on the needs of the company as long as the service is needed by the company. The labour force will be terminated once the project is completed successfully or the service is no longer needed by the company [14].

\section{A. Advantages of Project-Based Employment}

Fresh graduates need to be more aware and prepared for the current job market situation. Graduates who are looking for opportunities can get more advantages through a system like project-based employment carried out by the industry now. This is because graduates are able to develop their skills after working through project-based employment. Once graduates enter the working environment, they will be given the opportunity by employers to show and develop their talents and skills.

In addition, project-based employment also will train and inspire the graduates to be more independent, open minded and more mature in decision making [15]. This is because the graduates will not be able to be too demanding, unproductive, and being dependent on their parents. Graduates who are self-reliant, open-minded and mature will find it easier to get a better job in the future.

Moreover, graduates will also be able to enhance their interpersonal skills through project-based employment. A degree without a solid personality does not guarantee success in the workplace. Their experience interacting with other personnel or third party through project-based employment can develop their interpersonal skills.

Furthermore, through project-based employment, graduates will also learn to manage their time better and be more positive. This is because graduates need to plan their career carefully to avoid being unemployed after the contract or job appointment is over. Graduates will always put themselves in a position to avoid the pressures of the surrounding environment [16]. They will become more organized and positive after going through project-based employment.

Graduates will also be able to learn and gain as much experience as possible during the project-based employment period. By gaining experience through project-based employment, graduates will be able to use their experience to get a better job in the future. Graduates who do not have experience in a particular field

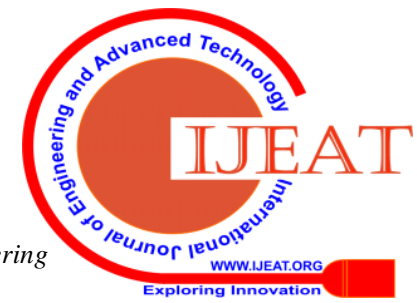


will keep working to get a new experience. The experience gained can be categorized as an advantage and highly valued by the employers. Most employers consider graduates with working experience as more mature and have a higher chance of getting a better job than other candidates [17].

On the other hand, employers also get many advantages on the implementation of project-based employment. Industry companies will benefit greatly as they only need to spend on employees who work within the period to complete the project. They can also select more semi-skilled workers with lower pay to complete the projects.

\section{B. Weaknesses of Project-Based Employment}

Although project-based employment has many positive impacts on the employees, it also has some negative impacts on the workforce that works through the project-based employment. One of the consequences is that the workforce has to work for several months to get a job based on the industry-acquired projects. To prevent unemployment, the workforce needs to be more prepared and able to take advantage of the existing job opportunities [18].

In addition, the workforce also has to bear the risk that the employer can terminate them in two ways; through 'just cause' and 'without cause' [19]. First, employers may terminate their employees for certain reasons. If an employee violates the rules, the project-based employment will be terminated. Some of these factors may be due to theft, illegal activity, fraud, violence or any other inappropriate behavior. Whereas the second method is the 'without cause' which means that the status of the job can be terminated just without any reason or action. This is when an employer wants to reduce the number of employees or the employees are not eligible to work in the company.

Due to this, to cope with project-based employment, new graduates need to compete more for jobs. This is because employers choose only qualified, highly confident workers project-based employment.

\section{SELF-MOTIVATION IN FRESH TECHNICAL GRADUATES}

In order to make our country more competitive, an effective education system is essential to produce a highly skilled workforce. Technical skills education is another important component of today's education for a highly skilled workforce. Besides, technical skills education is also crucial to attain and enable an economic vision like other industrial countries such as Japan, Germany, Taiwan and South Korea. However, Malaysia still lacks high-skilled students in technical skills especially among the youngsters.

Therefore, lecturers are required to enhance self-motivation of the technical students to meet their diverse needs especially for students to face project-based employment. Elements of self-motivation such as self-confidence, self-awareness and initiative are needed [20] to ensure that the students are able to translate ideas and develop their mind and skills. who have high self-awareness and initiative in dealing with

Fresh technical graduates are fresh graduated students who have an interest in technology and engineering education to meet the needs of the workforce both in the industry and abroad. These fresh graduates will likely be trained to become professional and semi-professional workforce in various fields of technology and engineering.

The change in a student's future career depends on his or her motivation. Today, institutions and industries are working and helping one another to equip students and fresh graduates with self-motivation elements. In addition to outstanding academic achievement, students and fresh graduates also need to have strong self-motivation elements including high self-confidence, self-awareness, initiative in grabbing opportunities, committed to doing things, optimistic about achieving ambitions and having deep interest in something [21].

The results of the study show that the employers prefer workers who have high self-esteem and are comfortable dealing with others. Graduates who have good self-awareness are also likely to attract employers compared to graduates who are only interested in something without knowing their capabilities. Employers also choose graduates who are innovative in their attitude compared to those who are optimistic but do not know how to seize opportunities and embrace change.

Furthermore, most employers have the mindset that good-quality graduates are those who can become efficient workforce, where the quality comes from the workers who have a strong motivation element. An efficient workforce will also be able to reduce the employers' dependence on foreign workers [22]. Graduates that are sought after by employers in today's workforce is not those who only concern about academic but also possess great technical skills and a strong self-motivation.

Therefore, the institution must emphasize the elements of motivation among their fresh graduates. This is because fresh graduates find it difficult to adapt to the job. In addition, many employers require graduates who are not only academically wise but also have skills and elements of self-motivation. The element of self-motivation is so important for all fresh graduates to put themselves in the work environment.

\section{A. Importance of Self-Motivation Elements in Project-Based Employment}

There are a lot of advantages for someone who is self-motivated. Self-motivated individuals are more likely to be organized, have good time management skills and have more confidence. Both employers and employees with good time management determine the success of a company. Employers in the industry desperately need workers who can manage their time efficiently. This is because graduates who can manage their time well and are orderly can help employers to be more focused and succeed [23]. 


\section{The Importance of Self-Motivation Elements in Preparing Fresh Technical Graduates to Face Project-Based Employment}

Moreover, students and graduates who understand and develop self-motivation within themselves are able to control many other aspects of their life better. Graduates will be able to handle a given task very well. Graduates will also be able to manage and complete their job on time. This causes employers in industries to value graduates' with self-motivation more that other candidates before hiring them. Other than that, self-motivated graduates also can easily find their own strength to complete a task, even in the face of challenges, without giving up or needing others to motivate them. Graduates who are able to solve problem and has initiated attitude are highly needed by employers in industrial companies. This is because they will help the employers solve the problem with minimum supervision. Employers will also put their trust in employees who can solve problems well and always have the initiative to grow the company further.

\section{B. Factors Affecting Elements of Self-Motivation}

Self-motivation will help students be more confident and have self-awareness. Besides having excellent academic achievement, students need to have strong self-motivation elements including confidence in communication and some other elements such as self-awareness and initiative. Employers are more likely to find qualified self-motivated workers without the need for in-house training [24].

One of the factors that influences one's motivational element is gender. There are women who dismiss gender issues because to them, self-esteem is more important in facing life challenges. That is why female students are viewed to have high self-esteem compared to male students. They are more bold in expressing their opinions and more open-minded.

According to a study in western countries, over $80 \%$ of workers are dismissed not because of unsuccessful work issues. They are dismissed because they have a problem with their attitude especially problems with their colleagues. In this case, male workers are easier to adjust and adapt to the new workplace. This is because they are more receptive to new situations and easier to associate with other colleagues [25].

For students, the field of specialization will focus more on the field of study to be pursued after graduation. The field of specialization is like the starting point for a career. It is also a factor that influences the motivational element of students. For example, the field of electrical has more limited careers as compared to the more specialized areas of construction.

Employees are an important aspect of any industry. If employees are able to master the elements of self-motivation, the industry will be able to achieve a higher level of excellence. With them, employers can better develop their company. If workers do not have sufficient element of self-motivation, it will be more challenging for employers in the industry to keep up and develop.

\section{CONCLUSION}

In conclusion, the elements of self-motivation are essential for students in the vocational institution. Therefore,

the elements of self-motivation should always be improved and embedded from time to time by the institutions to ensure that the graduates produced are equipped with strong self-motivation. Graduates of vocational institutions should also be prepared for project-based employment system for a place in the job market later. Self motivation is viewed as a very important element by the employers as they require skilled and competent employees from various aspects to help improve the quality of work so as to cope with project-based employment.

\section{ACKNOWLEDGMENT}

This research work is a funded research awarded by Research Management Centre, Universiti Tun Hussein Onn Malaysia (UTHM) Johor under Geran Penyelidikan Pascasiswazah (GPPS), Vot No, H329.

\section{REFERENCES}

1. Hamidi. A. Z. (2018). Sistem Pendidikan Mampu Lahir Modal Insan Berkualiti. Universiti Tun Hussein Onn Malaysia.

2. Yusof, N. \& Jamaluddin, Z. (2017). Pembangunan Kebolehpasaran Siswazah: Tindakan Universiti dan Cabaran yang Dihadapi. Jurnal Personalia Pelajar 20, (2017): 15-32.

3. Mohd Majid, A. (2012). Pemahaman Syarat-syarat Kontrak Pembinaan. Juruukur Bahan. Kontrak dan Juruukur Bahan. JKR Malaysia.

4. Rasul, M. S., Ismail, M. Y. \& Rajuddin, R. (2012). Aspek Kemahiran-kemahiran yang Dikehendaki Majikan Industri Pembuatan Masa Kini. Jurnal Pendidikan Malaysia 34(2)(2012): 67 - 79.

5. Che Mat Zain, F. (2015). Kemahiran Insaniah Meningkatkan Kemahiran Mahasiswa sebagai Persediaan Menempuhi Alam Pekerjaan. Fakulti Pendidikan (Ekonomi), Universiti Kebangsaan Malaysia.

6. Ryan G. Carlson, Naomi J. Wheeler, Justin J. Adams. (2018). The Influence of Individual-Oriented Relationship Education on Equality and Conflict-Related Behaviors. Journal of Counselling and Development. Vol 96, Issue 2. Pages: 144-154.

7. Widayat, P. (2015). Teori-Teori Motivasi. Jurusan Ilmu Perpustakaan dan Komunikasi Universitas Islam Negeri Ar-raniry. Jurnal Adabiya, Vol. 1 No. 83 Tahun 2015.

8. Antonino, C., Flavio, U. \& Emanuela, I. (2014). The Relationship Between Contract Type And Job Satisfaction In A Mediated Moderation Model: The Role Of Job Insecurity And Psychological Contract Violation. Volume: 37 issue: 2, page(s): 399-420. SAGE Publications, [2014].

9. Dabas, D \& Pandey, N. (2015). Role of Self-Motivation and Intrinsic Motivation on Work Place. International Journal of Education and Psychological Research (IJEPR). Volume 4, Issue 1, March 2015.

10. Richard S. Balkin. (2010). What Is Professional Self-Counseling. American Counseling Association.

11. Arif Nurhadi, M. \& Teuku, T. K. (2014). Pelaksaaan Kontrak Kerja Jasa Kontruksi Mengenai Pembuatan Jembatatan Andalas Padang Antara Perseroan Umum dengan CV. Duta Graha Padang.

12. Jabar. (2017). Keuntungan \& Kerugian Pekerja Kontrak. Artikel, Kontributor.

13. Ishak, W. S. (2013). Factors Influencing Construction Worker Job Satisfaction In The Construction Industry. Universiti Malaya. Kuala Lumpur. Tesis Sarjana.

14. Ismail, N. (2012). Penamatan Kontrak Kerja. Kementerian Sumber Manusia (KSM).

15. Thanam, B. (2015). Hubungan Sikap, Pemikiran Dan Tingkah Laku Terhadap Keinginan Dalam Pemilihan Kerjaya Dalam Kalangan Prasiswazah Diinstitut Pengajian Tinggi Sekitar Bangi. Fakulti Pendidikan Universiti Kebangsaan Malaysia Bangi. Tesis Sarjana Pendidikan.

16. Abdullah, A. H. \& Sulaiman, A. A. (2015). Faktor-Faktor Yang Mempengaruhi Motivasi Pekerja Terhadap Organisasi. Universiti Kebangsaan Malaysia. Jurnal Islam dan Masyarakat Kontemporari. Bil 102015 . 
17. Praabhu, A. \& Jayam, R. (2012). Motivation Strategy at Work Place. International Journal of Scientific Research 2(4):202-203.

18. Marcos, S. \& Sridev, M. S. (2010). Employee Engagement: The Key To Improving Performance. International Journal of Business and Management. Volume 5, No 12.

19. Jabar. (2017). Definisi Kontrak Kerja. Artikel, Kontributor.

20. Abdul Malek, N. H. \& Ikhsan, Z. (2014). Persepsi Pelajar Terhadap Pembelajaran Berasaskan Projek Dan Hubungannya Dengan Sikap Pelajar Terhadap Sains. International Seminar on Global Education. Fakulti Pendidikan, Universiti Kebangsaan Malaysia. Tesis Sarjana.

21. Fareed, K. A (2016). Self-Motivation - Importance Of Self-Motivation. Institute of Management Consultants of India.

22. Mohd Yusof, H. (2014). Penilaian Kemahiran Employability dalam Kalangan Pelajar Kejuruteraan Politeknik di Semenanjung Malaysia. Tanjung Malim: Thesis PhD. Universiti Pendidikan Sultan Idris (tidak diterbitkan).

23. Makhbul, Z. M. \& Yussof, I. (2012). Kriteria Pengambilan Dan Pemilihan Graduan Dari Perspektif Pengurusan Sumber Manusia. Jurnal Personalia Pelajar 15 (2012):1 -11.

24. Che Darus, N. (2017). Persepsi Majikan terhadap Kemahiran Pekerja. Universiti Malaysia Sarawak

25. Affan, O. (2017). Kemahiran Berkawan. Smart Study Consultant Sdn. Bhd.

\section{Authors Profile}

Siti Nur Maizura Binti Sharberi is a postgraduate student in Technical and Vocational Education at Universiti Tun Hussein Onn Malaysia (UTHM). She studied at the Kolej Kemahiran Tinggi Mara (KKTM) and obtained a Diploma in Building Engineering Technology in 2014. She then pursued a Bachelor of Vocational Education (Building Construction) degree with honors at Universiti Tun Hussein Onn Malaysia (UTHM) in 2018.

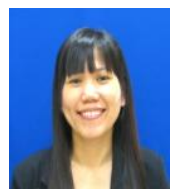

Dr Yee Mei Heong is the senior lecturer for the Department of Engineering Education (JPK) at the Faculty of Technical and Vocational Education of Universiti Tun Husseion Onn of Malaysia (UTHM). She graduated with a Bachelor of Technology in Education (Civil Engineering) with honors at the Universiti Teknologi Malaysia in 2002, and then went on to pursue a Master of Technical and Vocational Education at the Universiti Teknologi Malaysia in 2005. She received a master's degree in Doctor of Education Philosophy Engineering and Vocational at Universiti Tun Hussein Onn Malaysia in 2015. She has teaching experience as a Graduate Educational Services Officer at Maktab Rendah Sains MARA Gerik, Perak for 3 years and a senior lecturer at UTHM for 10 years. She is currently the chair of the Doctor of Education Philosophy Program since 2014. Shee also served as chair of the brick lab in 2014-2016. Her academic expertise includes teaching and learning problem solving skills. She has published over 90 articles / journals / teaching modules / books / book chapters in his area of expertise.

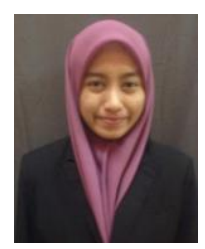

Raudhah Adibah Binti Ahmad Zubir is a postgraduate student in Technical and Vocational Education at Universiti Tun Hussein Onn Malaysia (UTHM). She studied at Politeknik Ungku Omar (PUO) and obtained a Diploma in Civil Engineering in 2014. She then pursued a Bachelor of Vocational Education (Building Construction) degree with honors at Universiti Tun Hussein Onn Malaysia (UTHM) in 2018. 